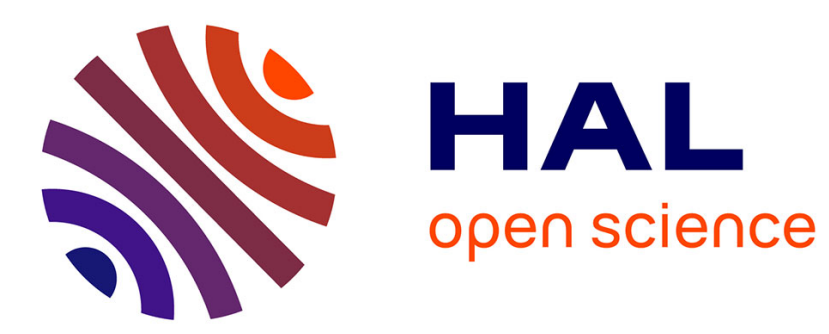

\title{
An Essay on Scribal Families, Tradition, and Innovation in Thirteenth Century Ugarit
}

Carole Roche-Hawley, Robert Hawley

\section{To cite this version:}

Carole Roche-Hawley, Robert Hawley. An Essay on Scribal Families, Tradition, and Innovation in Thirteenth Century Ugarit. B. J. Collins \& P. Michalowski. Beyond Hatti: A Tribute to Gary Beckman, Atlanta, Lockwood Press, pp.241-264, 2013, 978-1-937040-11-6. halshs-00924303

\section{HAL Id: halshs-00924303 https://shs.hal.science/halshs-00924303}

Submitted on 6 Jan 2014

HAL is a multi-disciplinary open access archive for the deposit and dissemination of scientific research documents, whether they are published or not. The documents may come from teaching and research institutions in France or abroad, or from public or private research centers.
L'archive ouverte pluridisciplinaire HAL, est destinée au dépôt et à la diffusion de documents scientifiques de niveau recherche, publiés ou non, émanant des établissements d'enseignement et de recherche français ou étrangers, des laboratoires publics ou privés. 


\title{
AN ESSAY ON SCRIBAL FAMILIES, TRADITION, AND INNOVATION IN $13^{\text {TH }}$ CENTURY UGARIT
}

\author{
Carole ROCHE-HAWLEY (CNRS, PARIS) and Robert HAWLEY (CNRS, PARIS)
}

\section{Introduction}

Gary Beckman's contributions to our knowledge and understanding of scribal traditions in Syro-Anatolia in the Late Bronze Age are well known. Even his early work, for example his 1983 study of "Mesopotamians and Mesopotamian Learning at Hattuša," ${ }^{1}$ has proven fundamental, and his interest in the subject has certainly not lagged in the intervening thirty years. ${ }^{2}$ It is a pleasure for us to offer him this short essay ${ }^{3}$ in his honor, with our gratitude for his learning, friendship and admirable humanity. In the spirit of Gary's own work, we have attempted here to move beyond habitual preoccupations with epigraphic and philological detail, and to place our inquiry within a broader and more meaningful historical and cultural context. We hope that his vast intellectual curiosity will find some small satisfaction in perusing the essay which follows - our own attempt to present a historical scenario that "makes sense" for the development of scribal traditions at Ugarit in the $13^{\text {th }}$ century.

\section{Colophons as Sources}

\subsection{Scribal Families to Be Expected}

It should come as no surprise that the scribal craft in the city of Ugarit in the $13^{\text {th }}$ century BC was a family affair. Such is the norm not only in the Ancient Near East more generally, ${ }^{5}$ but also in northern Syria in the Late Bronze Age in particular, as shown for example by the Emar archives. ${ }^{6}$ Furthermore, in more general terms, among members of a specialized craft, that is, among artisans, it is also common cross-culturally to find fathers apprenticing their sons. ${ }^{7}$ This makes economic

${ }^{1}$ G. Beckman, "Mesopotamians and Mesopotamian Learning at Hattuša," JCS 35 (1983) 97-114. Abbreviations used in this study, beyond those standard in Assyriology, include "CTA" : A. Herdner, Corpus des tablettes en cunéiformes alphabétiques découvertes à Ras Shamra-Ugarit de 1929 à 1939, Mission de Ras Shamra 10, Bibliothèque Archéologique et Historique 79 (Paris: Imprimerie Nationale and Geuthner, 1963); "KTU" : M. Dietrich, O. Loretz, and J. Sanmartín, The Cuneiform Alphabetic Texts from Ugarit, Ras Ibn Hani and Other Places (KTU: second, enlarged edition), Abhandlungen zur Literatur Alt-Syrien-Palästinas und Mesopotamiens 8 (Münster: Ugarit-Verlag, 1995); "RS" and "RIH" refer to the inventory number of a text from Ras Shamra or Ras Ibn Hani, respectively, for which see P. Bordreuil and D. Pardee, La trouvaille épigraphique de l'Ougarit, volume 1: Concordance, Ras Shamra-Ougarit 5 (Paris: Éditions Recherche sur les Civilisations, 1989).

${ }^{2}$ For example, Beckman, "Gilgamesh in Hatti,' in Hittite Studies in Honor of Harry A. Hoffner, Jr., on the Occasion of His 65th Birthday, ed. G. Beckman, R. Beal, and G. McMahon (Winona Lake: Eisenbrauns, 2003), 37-58; idem, "Ugarit and Inner Syria during the Late Bronze Age," in Le royaume d'Ougarit de la Crète à l'Euphrate: Nouveaux axes de recherche Actes du Congrès Internationale de Sherbrooke 2005, ed. J.-M. Michaud (Sherbrooke, Québec: Éditions G.G.C. Itée, 2007), p. 163-174.

${ }^{3}$ A preliminary version of this paper was read at the $55^{\mathrm{e}}$ Rencontre assyriologique internationale in Paris, 2009.

${ }^{4}$ Beckman, “The Limits of Credulity," JAOS 125 (2005) 343-352 (in particular, p. 346).

${ }^{5}$ B. Alster, "Scribes and Wisdom in Ancient Mesopotamia," in Scribes, Sages, and Seers: The Sage in the Eastern Mediterranean World, ed. L. Perdue, Forschungen zur Religion und Literatur des Alten und Neuen Testaments 219 (Göttingen, Vandenhoeck \& Ruprecht, 2008) 47-63 (esp. p. 50); K. van der Toorn, Scribal Culture and the Making of the Hebrew Bible (Cambridge: Harvard University Press, 2007) 61-67; and D. Carr, Writing on the Tablet of the Heart: Origins of Scripture and Literature (Oxford: Oxford University Press, 2005) 20-22 (all with further bibliography).

${ }^{6} \mathrm{Y}$. Cohen, The Scribes and Scholars of the City of Emar in the Late Bronze Age, Harvard Semitic Studies 59 (Winona Lake: Eisenbrauns, 2009).

${ }^{7}$ For Mesopotamia, for example, van der Toorn, Scribal Culture, 62, cites the dictum "The son takes the profession of his father" from a Sumerian literary text (for a transcription, see A. Sjöberg, "Der Vater und sein missratener Sohn," JCS 
sense, since, among other reasons, the acquisition of a trade or craft, especially of a craft that was coveted or highly valued by the powers that be, was a good means of ensuring the economic and social security not just for a given individual, but also for several generations of his family.

\subsection{Limited Data for Scribal Families at Ugarit}

Because of the limited nature of the textual documentation from Ugarit, however, both in terms of numbers of tablets and fragments, and in terms of the types and amount of information conveyed, only a limited amount of evidence for scribal families is available for study.

This evidence is both direct and indirect. The indirect evidence is the (often assumed) hereditary status of the scribal profession; these data derive from the juridical corpus: several royals acts fall into a category often called "appointments" or "promotions" in which the king effects the legal transfer of a named individual from one professional category into another. ${ }^{8}$ The appointment often explicitly involves not only the named individual but also his descendants (i.e., it is hereditary); moreover it is often said to be effective "forever" (i.e., it is perpetual).

Superficially, the presence of these heritability and perpetuity formulas might seem to suggest that professional status or membership was generally hereditary at Ugarit. ${ }^{9}$ While it is true that such an inference is consistent with the educational dictum "The son takes the profession of his father", ${ }^{10}$ and indeed such a conclusion certainly also makes good intuitive sense, even so, the mere presence of the heritability and perpetuity formulas in particular examples of royal "appointments" does not necessarily demonstrate the general hereditary character of professional status and membership at Ugarit. Such an inference, however likely, is potentially problematic because it is based on data derived from the juridical corpus, and there is no way to know whether the kinds of privileges conveyed in legal contracts were typical or atypical. Indeed, there is good reason to believe that it was the atypical, and not the typical that required the drafting of a royal act. In general, at Ugarit as elsewhere, situations that were consistent with commonly established practice probably required no documentation; it was the exceptional situations that required documentation. ${ }^{11}$ For all we know, the "exception" (which triggered the setting down in writing of some or all of the preserved "appointments") may very well have been the hereditary and perpetuity clauses. Thus, in our opinion, the indirect data from the juridical corpus are merely suggestive and corroborative, and do not themselves constitute firm evidence that the scribal craft was hereditary at Ugarit.

The direct evidence, however, is less ambiguous (although still occasionally problematic), and in any case it is the more important for our discussion. It is basically limited to one category of data: scribal colophons in which genealogical information is provided. Outside of scribal colophons,

25 (1973) 112; for a translation, ibid., p. 117: “Das, was Enlil den Menschen bestimmt hat, ist, Dass der Sohn dem Beruf seines Vaters folge").

${ }^{8}$ J. Huehnergard, The Akkadian of Ugarit, Harvard Semitic Studies 34 (Atlanta: Scholars Press, 1989), 325-326, provides a list of the documents (labelled as "appointments"). For annotated translations, see S. Lackenbacher, Textes akkadiens d'Ugarit: Textes venant des vingt-cinq premières campagnes, LAPO 20 (Paris: Les Éditions du Cerf, 2002), 238-241, 291292 (labelled "dons-nominations [mutations]"); and for a description of this category as a whole, see I. Márquez Rowe, The Royal Deeds of Ugarit: A Study of Ancient Near Eastern Diplomatics, AOAT 335 (Münster: Ugarit-Verlag, 2006), 245-246 (labelled "promotions").

${ }^{9}$ These same formulas are ubiquitous in the much larger corpus of royal land grants, for example, and their frequent presence there is generally assumed to indicate that "heritability was the norm" (J. D. Schloen, The House of the Father as Fact and Symbol: Patrimonialism in Ugarit and the Ancient Near East, Studies in the Archaeology and History of the Levant 2 [Winona Lake: Eisenbrauns, 2001] 244); see also Márquez Rowe, Royal Deeds of Ugarit, 249-253 (both with further bibliography).

${ }^{10}$ See above, note 7.

${ }^{11}$ R. Westbrook, "The Character of Ancient Near Eastern Law," in A History of Ancient Near Eastern Law, ed. R. Westbrook, Handbook of Oriental Studies, Section One, The Near and Middle East 72 (Leiden: Brill, 2003 ), 11. 
one also frequently encounters patronymics in the administrative corpus, but it is usually not possible to affirm that a person named in the administrative lists was necessarily a scribe.

\subsection{Types of Colophons}

The data used in preparing this study are thus almost exclusively limited to the scribal colophons. Defined broadly, "colophons" in the epigraphic corpus from Ugarit are found appended to two different types of documents:

- "traditional texts"12 in Mesopotamian cuneiform script, mostly scholarly lexical lists and literary compositions; and

- documents from daily life, in particular juridical acts, mostly in Mesopotamian cuneiform script, mostly royal, and mostly having to do with land tenure in one way or another.

In the case of the latter group, the juridical acts, the scribal colophon probably has a very practical purpose..$^{13}$ In the school texts, however, the presence of a scribal colophon seems not so much practical as traditional: it was part of what one learned to do when one learned the Mesopotamian cuneiform writing system and the languages associated with it. A quick comparison of the formal patterns of the colophons attested at Ugarit ${ }^{14}$ with some of the Old Babylonian colophons surveyed by Hermann Hunger ${ }^{15}$ illustrates the extent to which this type of colophon is simply traditional.

\subsection{Past Scholarship}

Fundamental previous work on questions such as those treated here, concerning the scribal craft and scribal education at Ugarit, has been done by Wilfred van Soldt in a series of publications since 1988. Our article is particularly indebted to three of his studies:

- a 1988 article containing the fullest available survey of the attested colophons on traditional texts from Ugarit, ${ }^{16}$

- his 1991 published dissertation, with a chapter containing the fullest available prosopographical study of the Ugaritian scribes, ${ }^{17}$ and

- a 1995 article containing the fullest available survey of scribal education at Ugarit. ${ }^{18}$

${ }^{12}$ In other words, these are texts which represent the Oppenheimian "stream of scribal tradition", those which Daniel Arnaud has called "textes de bibliothèque" (as in Arnaud, Corpus des textes de bibliothèque de Ras Shamra-Ougarit (19362000) en sumérien, babylonien et assyrien, Aula Orientalis-Supplementa 23 [Barcelona: Sadabell, 2007], for example).

${ }^{13}$ The scribe essentially presents himself at the end of the list of witnesses (probably presenting himself as one of them, despite the frequent lack of the sign IGI preceding the scribe's name) who guarantee and could potentially vouch for the authenticity of the transaction recorded, and to whom recourse could potentially be made should there be a subsequent dispute. See also Márquez Rowe, Royal Deeds of Ugarit, 206-208.

${ }^{14}$ For a convenient typology of their compositional elements, see W. van Soldt, "The Title T' Y," UgaritForschungen 18 (1988) 314-318.

${ }^{15} \mathrm{H}$. Hunger, Babylonische und assyrische Kolophone, AOAT 2 (Kevelaer and Neukirchen-Vluyn: Butzon \& Bercker and Neukirchener Verlag, 1968), 25-34.

${ }^{16}$ Van Soldt, "The Title T' Y."

${ }^{17}$ Idem, Studies in the Akkadian of Ugarit: Dating and Grammar, AOAT 40 (Kevelaer and Neukirchen-Vluyn: Butzon \& Bercker and Neukirchener Verlag, 1991), 19-32.

${ }^{18} \mathrm{Idem}$, "Babylonian Lexical, Religious and Literary Texts and Scribal Education at Ugarit and Its Implications for the Alphabetic Literary Texts," in Ugarit: ein ostmediterranes Kulturzentrum, Ergebnisse und Perspektiven der Forschung, I: Ugarit und seinem altorientalische Umwelt, ed. M. Dietrich and O. Loretz, Abhandlungen zur Literatur Alt-Syrien-Palästinas 7 (Münster: Ugarit-Verlag, 1995), 171-212. 


\section{Families and Scribal Traditions: The Case of $\mathrm{Nu}$ ' $m \bar{i}$-Rašap and Sons}

No less that forty-eight individual scribes are listed in van Soldt's prosopographical survey of the scribes of Ugarit in his published dissertation. ${ }^{19}$ Of these, it is possible to use the colophon data to suggest some sort of family connection for at least fourteen cases. Such connections are not to be taken as absolutely certain, but they are probable, as can be seen from the example presented below in fig. 1.

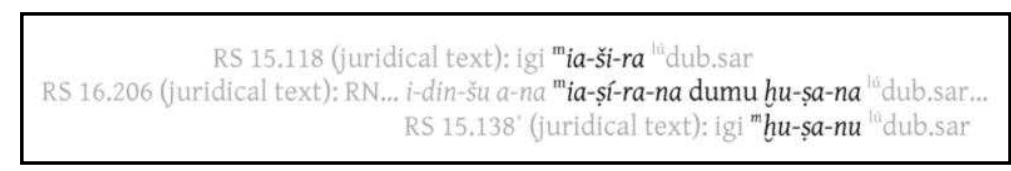

fig. 1. An example of a "probable" family connection in the juridical corpus ${ }^{20}$

If we lay out a rough relative chronology of these fourteen scribes linked by such plausible family connections (fig. 2), we observe that the heaviest concentration (and also the most reliable) of the data derive, as one might expect, from the latest documented period at Ugarit, the last fifty years or so prior to the destruction of the city.

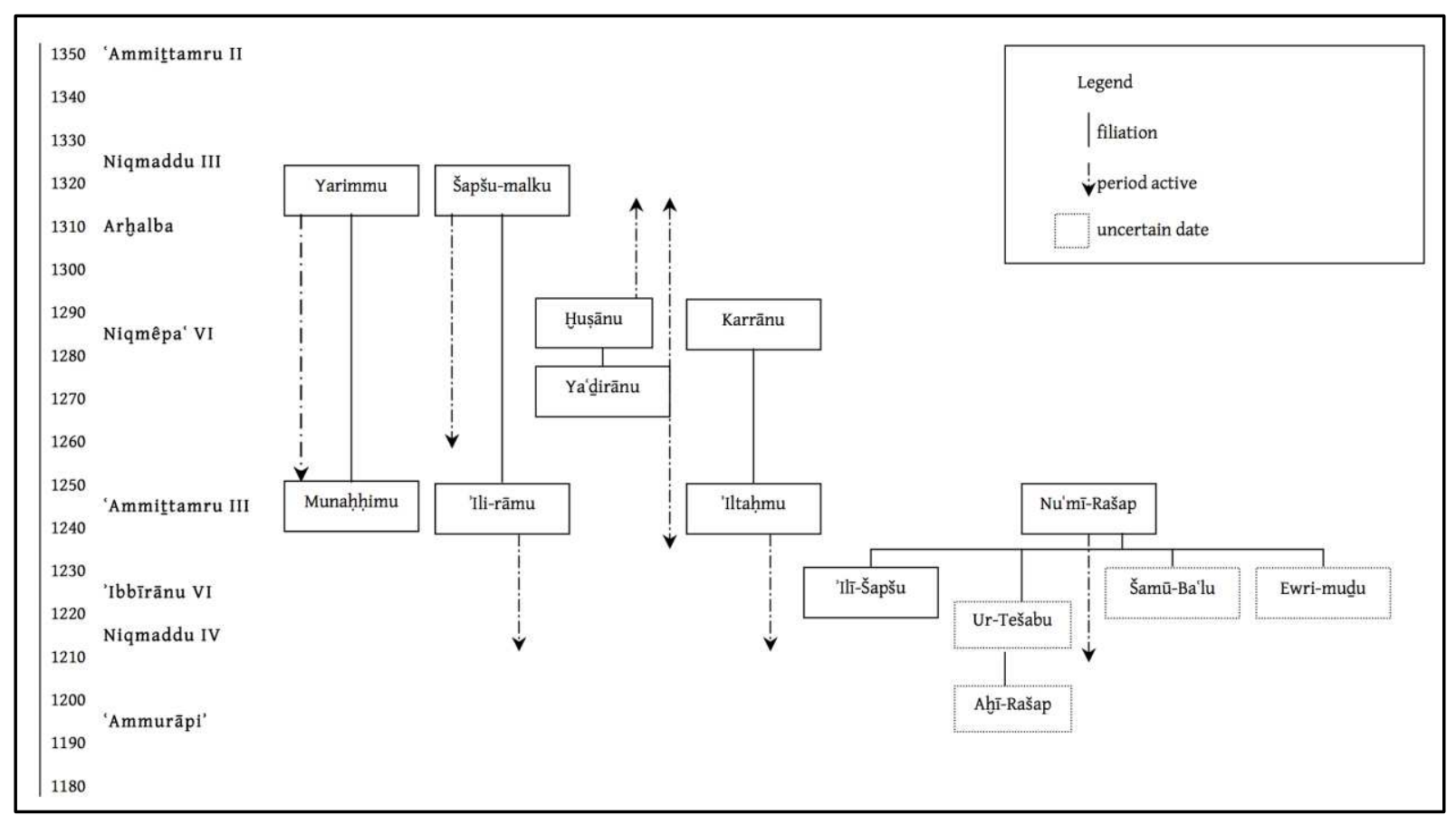

fig. 2. Schematic diachronic presentation of Ugaritian scribal families

From this presentation, one family emerges as particularly active in the archives of $13^{\text {th }}$ century Ugarit: that of a certain $\mathrm{Nu}$ ' mì-Rašap.

${ }^{19}$ Idem, Studies in the Akkadian of Ugarit, 19-26. We have not taken into consideration the fragmentary names grouped under $n^{\circ} 49$.

${ }^{20}$ RS 16.206 is actually one of the rare examples in which genealogical information can be gleaned from the actual body of a juridical text, and not merely from the colophon (as in the two other cases cited). Despite the high proportion of homonymy in Ugaritian onomastics, given the limited number of scribes likely to have been active at any given time, and given the fact that Husānu and $Y a^{\prime}$ dirānu were both scribes and were both active during the reign of Niqmêpa' VI (Ya' dirānu remained active also during the following reigns), it is highly probable that Ya' dirānu's father (whose name was Hușānu) and the scribe Hușānu who was a slightly earlier contemporary, were in fact one and the same person. Here and throughout, our numbering of the Ugaritian homonymous kings follows Arnaud, "Prolégomènes à la rédaction d'une histoire d'Ougarit II: Les bordereaux de rois divinisés," Studi Micenei ed Egeo-Anatolici 41 (1999) 153-173. 


\subsection{The Prestigious Status of Nu' mì-Rašap}

The scribe $\mathrm{Nu}$ ' mi-Rašap, son of 'Abaya, was active in the $2^{\text {nd }}$ half of the $13^{\text {th }}$ century $\mathrm{BC} .^{21}$ The period of activity spans a rather long period: he is attested under three successive reigns. ${ }^{22}$ Texts which he signed have been found in and near ${ }^{23}$ the Palais royal, in the Ville sud, and in the Quartier résidentiel. ${ }^{24}$

By the end of his career, he must have attained a position of high rank or status, since he is responsible for writing an international juridical text in which one of the parties involved is the king of Ugarit himself, Niqmaddu IV. ${ }^{25}$

On intellectual and literary levels as well, his prestige (or, at least, pretensions) within local Ugaritian scribal circles is illustrated by the fact that he not only wrote juridical texts (a total of nine legal contracts which he wrote are preserved), but also copied Babylonian Belles-lettres, as shown by his fragmentary copy of the Flood pericope from a local recension of Gilgameš or Atrahasisis. ${ }^{26}$ Even more striking in this regard is his frequent use of esoteric or "learned" spellings, thus distancing himself from the mundane writings used by other scribes in their daily, non-literary productions. One such example ${ }^{27}$ is his use of the logogram SAG (instead of the more banal ìn) for "servant" in one of his colophons. ${ }^{28}$ Another example is found in the legend inscribed on one of his personal seals: $:^{29}$ he uses the logogram A.BA ${ }^{30}$ instead of the more banal DUB.SAR for "scribe".

${ }^{21}$ Earlier studies of $\mathrm{Nu}$ ' mï-Rašap's family include van Soldt, Studies in the Akkadian of Ugarit, 181, and especially the more detailed presentation in Malbran-Labat and Roche, "Urtēnu Ur-Tešub," in Le royaume d'Ougarit de la Crète à l'Euphrate : Nouveaux axes de recherche Actes du Congrès Internationale de Sherbrooke 2005, ed. J.-M. Michaud (Sherbrooke, Québec: Éditions G.G.C. Itée, 2007), 81-98.

${ }^{22}$ Synchronisms exist with 'Ammittamru III, ' Ibbirānu VI, and Niqmaddu IV.

${ }^{23}$ For example, between the Palais royal and the "Résidence de Yabninu." Here and throughout, references to the archeological contexts of various archives and isolated epigraphic finds are consistent with those by M. Yon, La cité d'Ougarit sur la tell de Ras Shamra, Guides archéologiques de l'Institut Français d'Archéologie du Proche-Orient 2 (Paris: Éditions Recherche sur les Civilisations, 1997).

${ }^{24}$ Malbran-Labat and Roche, "Urtēnu Ur-Tešub," 81-82.

${ }^{25}$ RS $17.371^{+}$.

${ }^{26}$ RS 22.421 (Ugaritica V, n 167); see J. Nougayrol, “Textes suméro-accadiens des archives et bibliothèques privées d'Ugarit," in Ugaritica V: Nouveaux textes accadiens, hourrites et ugaritiques des archives et bibliothèques privées d'Ugarit, Commentaires des textes historiques, première partie, ed. J.-C. Courtois, Mission de Ras Shamra 16, Bibliothèque Archéologique et Historique 80 (Paris: Imprimerie Nationale, 1968), 300-304; W. G. Lambert and A. Millard, Atra-hasis: The Babylonian Story of the Flood (Oxford: Clarendon, 1969), 131-133.

${ }^{27}$ For some further examples of his "learned", esoteric, or even "precious" writings, see C. Roche, "Jeux de mots, jeux de signes en Ougarit ou de l'influence des textes lexicaux sur les scribes de périphérie," in D'Ougarit à Jérusalem: Recueil d'études épigraphiques et archéologiques offert à Pierre Bordreuil, ed. C. Roche, Orient \& Méditerranée 2 (Paris: de Boccard, 2008), 210-211.

${ }^{28}$ See above, note 26.

${ }^{29}$ RS 29.100, for example, bears the impression this seal; its inscriptions reads: ${ }^{\mathrm{NA} A} \mathrm{KIŠIB}{ }^{\mathrm{m}} n u-m i{ }^{-}{ }^{\mathrm{d}} \mathrm{MAŠ} . \mathrm{MAS}{ }^{\text {LÚ }} \mathrm{A} . \mathrm{BA}$, "Seal of $N u^{\prime}$ mì-Rašap, scribe."

${ }^{30}$ The use of the logogram A.BA for local *sāpiru (Akkadian țupšarru), "scribe", deserves a few comments. V. Hurowitz has recently referred to the Assyriologist S. Parpola's suggestion "that the logogram LU A.BA used for țupšarru, "scribe”, as early as Ugarit, means 'A-BA man', 'ABC man', or 'alphabet man”" (cited in V. Hurowitz, "Additional Elements of Alphabetical Thinking in Psalm XXXIV," Vetus Testamentum 52 (2002) 333; further bibliography: ibid., note 22, and W. W. Hallo, Origins: The Ancient Near Eastern Background of Some Modern Western Institutions [Leiden: Brill, 1996], 40). Also according to H. Tadmor, "The Aramaization of Assyria: Aspects of Western Impacts," in Mesopotamien und seine Nachbarn. Politische und kulturelle Wechselbeziehungen in alten Vorderasien vom 4. bis 1. Jahrtausend v. Chr. XXV. Rencontre assyriologique internationale Berlin, Juli 1978, ed. H. J. Nissen and J. Renger, Berliner Beiträge zum Vorderen Orient 1 (Berlin: Reimer, 1982), 459, “the 'pseudo-logogram' ... should be interpreted as 'ABC-man' and ... it seems to have a western background, since it already occurs in Ugarit ... where this 'pseudo-logogram' seems to have originated." While this interpretation is in many ways seductive, it should be nuanced by the following three considerations. First, had $N u^{\prime}$ mì-Rašap himself been aware of 


\section{2 Šamū-Ba' lu son of $\mathrm{Nu}$ ' mì-Rašap: Teacher, Diviner, and Priest?}

The second generation of this scribal family is attested by no less than four sons, all of them scribes. ${ }^{31}$ Two of them ${ }^{32}$ are not yet attested as scribes in the corpus of texts from daily life: they appear as scribes only in school texts. In fact, one son, Ewri-mudu, known from three colophons, ${ }^{33}$ presents himself as having been a student of his own brother (whose name is written $\left.{ }^{\mathrm{m}} \mathrm{BAD}-{ }^{\mathrm{d}} \mathrm{IM}\right){ }^{34}$

This scribe whose name is written ${ }^{\mathrm{m}} \mathrm{BAD}-{ }^{\mathrm{d}} \mathrm{IM}\left(\right.$ or $\left.{ }^{\mathrm{m}} \mathrm{BAD}-{ }^{\mathrm{d}} \mathrm{U}\right)$ is attested as a teacher in three colophons, all on extracts from the HAR-RA: hubullu thematic lexical series, found in several different archives. ${ }^{35}$ Wilfred van Soldt had proposed to read this scribe's name as Gamir-Haddu: reading BAD as TIL, whose Akkadian reading is gamru "complete", and this sound in turn evoking the Semitic onomastic element *gāmiru, "hero" (which is also a productive Ugaritic noun). ${ }^{36}$

We now believe that the name is not to be read as ${ }^{\mathrm{m}}$ TIL- ${ }^{\mathrm{d}} \mathrm{IM}$, but rather as ${ }^{\mathrm{m}}$ IDIM- ${ }^{\mathrm{d}}$ IM, that is, Šamū-Ba' lu. ${ }^{37}$ Indeed, the IDIM sign is attested as a logogram noting the "deified heavens", *šamūma in Ugaritic (šam $\bar{u}$ in Akkadian), in six sacrificial lists. ${ }^{38}$ Both in its older graphic form, ${ }^{39}$ and in its contemporary Late Bronze form, ${ }^{40}$ which had merged with the BAD sign, IDIM is used interchangeably with AN for denoting "the divine heavens" in these lists. Thus, we allow the potential graphic equivalence of:

$$
\text { (logogram) AN = (logogram) IDIM = ("reading" in Ugaritic) šamūma (̌̌amū in construct })
$$

any putative alphabetic reference for the writing A.BA, it seems unlikely that he would have chosen it for his seal, where prestige seems to have been his concern ( $\mathrm{Nu}$ ' mi-Rašap and his family are associated above all with the Mesopotamian cuneiform script, and not the nascent cuneiform alphabet). Secondly, judging from RS 19.159 (see R. Hawley, "Apprendre à écrire à Ougarit : Une typologie des abécédaires," in D'Ougarit à Jérusalem: Recueil d'études épigraphiques et archéologiques offert à Pierre Bordreuil, ed. C. Roche, Orient \& Méditerranée 2 [Paris: de Boccard, 2008], 220, 224-225, with further bibliography), the first two signs of the local alphabetic inventory were pronounced $a$-be, not $a$-ba. Finally, since examples of this logogram are known from $13^{\text {th }}$ century Assyria, dated from Tiglath-Pileser I or even Tukulti-Ninurta (Hunger, Babylonische und assyrische Kolophone, 32 [ $\mathrm{n}^{\circ}$ 52]; O. Pedersén, Archives and Libraries in the City of Assur: A Survey of the Material from the Geman Excavations, Part I, Studia Semitica Upsaliensia 6 [Uppsala: Almqvist \& Wiksell, 1985], 31-42; ibid., Part II, Studia Semitica Upsaliensia 8 [Uppsala: Almqvist \& Wiksell, 1986], 24 [ $n^{\circ} 89$ ]), chronology also poses a problem. Is it feasible to imagine the direct, almost immediate influence of Ugaritian scribal habits in $13^{\text {th }}$ century Assur? Influence in the opposite direction appears to us much more likely (Arnaud, Corpus des textes de bibliothèque, 9-11)?

${ }^{31}$ Their names are 'Ili-Šapšu, Ur-Tešabu, Ewri-mududu, and a fourth whose name is written ${ }^{\mathrm{m} B A D-}{ }^{\mathrm{d}} \mathrm{IM}$ (or $\left.{ }^{\mathrm{m} B A D-}{ }^{\mathrm{d}} \mathrm{U}\right)$.

${ }^{32}$ Ewri-mudu and the scribe whose name is written ${ }^{\mathrm{m}} \mathrm{BAD}-{ }^{\mathrm{d}} \mathrm{IM}\left(\right.$ or $\left.{ }^{\mathrm{m}} \mathrm{BAD}-{ }^{\mathrm{d}} \mathrm{U}\right)$.

${ }^{33}$ One of the Ras Shamra manuscripts of the Weidner God List carries his colophon. He also signed two extracts of the thematic word list HAR-RA : hubullu. Yet another school text might also be his work, but the colophon there is broken: one can read the phrase "student of ${ }^{\mathrm{m} B A D}-{ }^{\mathrm{d}} \mathrm{U}$ ", so Ewri-mudu is a possibility, but not a certainty, since at least one other attested scribe, [...]-la-na, also studied with that particular teacher (i.e., he called himself "student of ${ }^{\mathrm{m} B A D-}{ }^{\mathrm{d}} \mathrm{U}$ "); RS $25.453^{+}$; van Soldt, "The Title T' Y," 316.

${ }^{34}$ From one of Ewri-mudu's colophons we learn that not only he, but also his teacher ${ }^{\mathrm{m}}$ BAD- ${ }^{\mathrm{d}}$ IM were both sons of

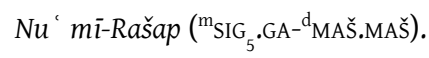

${ }^{35}$ Three colophons contain the phrase "(So-and-so), scribe, student of "mAD- ${ }^{\mathrm{d}} \mathrm{IM}$ ": from the Maison de Rap' ānu, from the "Maison aux textes magiques" and from the "Maison aux textes littéraires."

${ }^{36}$ Van Soldt, "The Title T' Y," 314, note 15; idem, Studies in the Akkadian of Ugarit, 20, note 179.

${ }^{37}$ This is a change of opinion with respect to Malbran-Labat and Roche, "Urtēnu Ur-Tešub," 83, and Roche, "Jeux de mots, jeux de signes," 212-213, where different interpretations were suggested.

${ }^{38}$ Roche-Hawley, "Procédés d'écriture des noms de divinités ougaritaines en cunéiforme mésopotamien," in Scribes et érudits dans l'orbite de Babylone, ed. C. Roche-Hawley and R. Hawley, Orient \& Méditerranée 9 (Paris: de Boccard, 2012), 151 (2.1.1), 169.

${ }^{39}$ The older form consists of two sequential AŠ, the second one being "reversed" (that is, pointing to the left).

${ }^{40}$ The Late Bronze form consists of the AŠ sign followed by the U sign. 
It appears plausible, then, that the writings ${ }^{\mathrm{m}} \check{s} a-m u-{ }^{\mathrm{d}} \mathrm{IM}$ and ${ }^{\mathrm{m}} \mathrm{AN}-{ }^{\mathrm{d}} \mathrm{U}$ are not only further alternative spellings of the same name ( $\breve{S} a m \bar{u}-B a^{\prime} l u$ ), but also that these writings both refer to the same person, since both refer to a diviner:

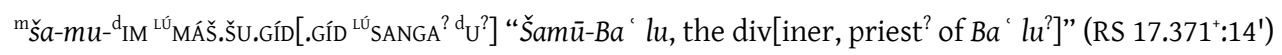

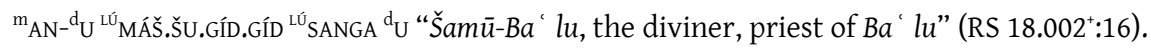

Furthermore, given the overall rarity of the name $\check{S}^{\prime} m \bar{u}-B a^{\prime} l u$, it appears likewise reasonable to identify Šamū- $B a^{\prime}$ lu the teacher (whose name is written ${ }^{\mathrm{m}}$ IDIM- ${ }^{\mathrm{d}} \mathrm{IM}$ or ${ }^{\mathrm{m}}{ }_{\mathrm{IDIM}}{ }^{\mathrm{d}} \mathrm{U}$ ), attested in colophons on school texts, with $\breve{S} a m \bar{u}-B a{ }^{\prime} l u$ the diviner (whose name is written ${ }^{m} \check{s} a-m u-{ }^{\mathrm{d}} I M$ and ${ }^{\mathrm{m}} \mathrm{AN}-{ }^{\mathrm{d}} \mathrm{U}$ ), attested as a witness in two international juridical acts written by $\mathrm{Nu}$ ' mì-Rašap (thus, his father, in our view). In our view, all of these writings refer to the same individual, $\breve{S} a m \bar{u}-\mathrm{Ba}$ ' lu son of $N u$ ' $m \bar{i}$ Rašap.

That a priest and diviner should also be scribe and teacher is not, in fact, surprising. In the

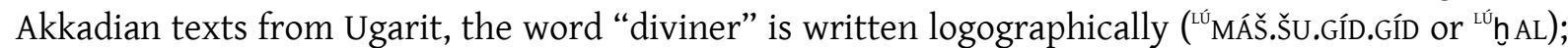
syllabic writings of the Akkadian word bārû are not attested outside of the school tradition. In a lexical list found in the House of Urtênu, for example, we find the following equivalence :

$$
\text { Lứh } \mathrm{AL}=b a-a-r u=w u-r u-u l-l i-n i^{41}
$$

The Hurrian word wu-ru-ul-li-ni (also written [p]u-ru-l[i $\left.i^{2}\right]-n\left[i^{2}\right]$ in RS $20.201 \mathrm{G}^{+42}$ ) shows up as a loan in alphabetic Ugaritic: the word prln, "diviner", is one of the titles attributed by the scribe 'Ilimilku $u^{43}$ to his teacher, whose name was 'Attēnu. ${ }^{44}$ Another of his titles in scribe 'Ilimilku's longest colophon is rb khnm, "chief of the priests", ${ }^{45}$ so the association of teacher-diviner-priest has good precedent at Ugarit.

Moreover, ' Ilimilku himself carries not only the title spr, "scribe", but also another title, t ' $y$ $n q m d$, "the $t \bar{a}$ ' iyu-official of (King) Niqmaddu." The precise semantic connotations of the title $\underline{t}^{\prime} y$ remain uncertain, but what is clear is that the word has definite cultic connotations, notably in the areas of sacrifice and exorcism. ${ }^{46}$ Furthermore, the explicit association of the title $t^{\prime} y$ with the royal name Niqmaddu in 'Ilimilku's colophons emphasize the political dimensions of the word. In fact, van Soldt has proposed to identify the logogram SUKKAL ${ }^{47}$ as the logographic equivalent in the locally written texts in Mesopotamian script of the Ugaritic title $\underline{t}^{\prime} y{ }^{48}$ a proposal further developed by Malbran-Labat and Roche..$^{49}$ Another of the titles worn by Šamū- $B a^{\prime} l u$ was GAL SUKKAL [LUGAL ${ }^{?} .^{50}$

${ }^{41}$ RS 94.2939 (see B. André-Salvini and M. Salvini, “Un nouveau vocabulaire trilingue sumérien-akkadien-hourrite de Ras Shamra," in General Studies and Excavations at Nuzi 10/2, ed. D. Owen and G. Wilhelm, Studies on the Civilization and Culture of Nuzi and the Hurrians 9 (Bethesda: CDL Press, 1998), 22-23.

${ }^{42}$ Ugaritica V, n 131 (J. Nougayrol, “Textes suméro-accadiens des archives et bibliothèques privées,” 234).

${ }^{43}$ See below, section 4.1 .

${ }^{44}$ Conveniently, see van Soldt, "Babylonian Lexical, Religious and Literary Texts," 187-188 (with further bibliography).

${ }^{45}$ Ibid.

${ }^{46}$ Pardee, Les textes rituels, Ras Shamra-Ougarit 12 (Paris: Éditions Recherche sur les Civilisations, 2000), 882 (with further bibliography), 1212.

${ }^{47}$ On the title SUKKAL, see below.

${ }^{48}$ Van Soldt, "The Title T' Y," 321 (translated "royal secretary").

${ }^{49}$ Malbran-Labat and Roche, "Urtēnu Ur-Tešub," 90-93.

${ }^{50}$ RS 25.453+. This is the only certain occurrence of this title. Another possible occurrence is RS $22.337 \mathrm{~A}+\left(\mathrm{x}^{-} \mathrm{d}_{\mathrm{IM}}\right.$ ${ }^{\mathrm{L}}$ GAL SUKKAL LUGAL), which may also refer to Šamū-Ba' lu. 
It thus seems reasonable to imagine $\check{S} a m \bar{u}-B a^{\prime} l u$ as the teacher of his brother, as a diviner ( ${ }^{L}$ MÁŠ.šU.GÍD.GíD) and as a priest ( ${ }^{1 \omega}$ SANGA) of the local storm god, $B a^{\prime} l u$. Beyond the local parallel in the case of 'Attēnu, described above, other pertinent parallels for the case of a diviner whose duties included teaching the scribal art may be found in contemporary Emar. ${ }^{51}$

\subsection{Ur-Tešabu son of Nu ' mi--Rašap: Scribe in the House of Urtênu}

Among $\mathrm{Nu}$ ' mi-Rašap's remaining sons, we may mention not only ' Ili-šapšu, ${ }^{52}$ who wrote two juridical acts, ${ }^{53}$ but above all Ur-Tešabu, ${ }^{54}$ well attested as a scribe in archives from the House of Urtênu.

Ur-Tešabu wrote three juridical acts recovered from those archives.$^{55} \mathrm{~A}$ fourth text, found in the Residential Quarter some years ago but not yet published, ${ }^{56}$ has a colophon that is broken at the beginning, but may very well be attributed to him. There, the scribe carries two titles, "scribe" and SUKKAL. In addition, the king of Ugarit calls him "my sUKKAL" in a letter from the House of Urtênu. ${ }^{57}$

Ur-Tešabu's activity is also attested in the administrative corpus. According to the correspondence recovered from the House of Urtênu, Ur-Tešabu was responsible for sealing certain shipments of goods on behalf of the high-ranking administrative official Urtênu. Three labels can be attributed to him. ${ }^{58}$ They carry the same seal impression, which, in two of the juridical texts is identified as being the "seal of Ur-Tešabu". Particularly interesting is the fact that one of these labels bears a text written in Ugaritic language and script, while in another the text is written in Mesopotamian cuneiform. ${ }^{59}$ The simplest explanation for such a situation is that Ur-Tešabu was trained to write in both scripts. ${ }^{60}$ Outside of the archives from the House of Urtênu, the name UrTešabu is only very rarely attested. ${ }^{61}$ This low frequency led Florence Malbran-Labat and Carole Roche to group all of the texts in which this name occurs in a single dossier. ${ }^{62}$

Finally, we know a little bit of the third generation of $N u$ ' mì-Rašap's family: 'Ahī-Rašap, son of Ur-Tešabu, like his uncle Ewri-mudu, left his colophon on one of the local manuscripts of the Weidner God List. ${ }^{63}$

${ }^{51}$ Cohen, Scribes and Scholars of the City of Emar, 38-40.

${ }^{52}$ In RS 22.223 the final element of his name is written ${ }^{\mathrm{d}} \mathrm{UTU}$-šu, indicating the reading Šapšu.

${ }^{53}$ RS 17.036 (an act established in the presence of witnesses, found in the Maison de Rašap-' abu) and RS 22.223 (a royal act found in the Maison aux textes magiques).

${ }^{54}$ In general, see Malbran-Labat and Roche, "Urtēnu Ur-Tešub," 81-98.

${ }^{55}$ None of them is royal; two are in the presence of witnesses, and a third is in the presence of "the elders of (the village of) 'Aru". Cf. Malbran-Labat and Roche, "Urtēnu Ur-Tešub," 84-87.

${ }^{56} \mathrm{Ibid}$.

${ }^{57} \mathrm{Cf}$. the title $\underline{t}^{\prime} y$ nqmd, "the $\underline{t} \bar{a}$ ' iyu-official of (King) Niqmaddu," in several of 'Ilimilku's colophons.

${ }^{58}$ One was found in the Maison d'Urtênu, and the two others near the Palais royal; Malbran-Labat and Roche, “Urtēnu Ur-Tešub," 85-86.

${ }^{59}$ One of these two labels (the alphabetic one) has to due with textiles destined for delivery to the professional corporation called the mur' $\bar{u}$ sākini, perhaps to be translated 'the prefect's guards (or officers)'; the other (in Mesopotamian cuneiform) mentions several large dūdu-measures (written GùR) of grain.

${ }^{60}$ Such an interpretation is preferable to the hypothesis according to which he would have merely impressed his seal on a label written by an alphabetic scribe.

${ }^{61} \mathrm{Ur}$-Tešabu is possibly also attested as a witness in a juridical text written by the scribe Rap' ānu (found in the Maison de Rap' ānu: RS 21.007A). The relevant line reads: [IGI...] $\mathrm{X}^{\mathrm{d}}{ }^{\mathrm{IM}}$ DUMU ${ }^{\mathrm{m}} \mathrm{SIG}_{5}-{ }^{\mathrm{d}}{ }^{\mathrm{MAŠ}} . \mathrm{MAŠ}$, perhaps to be reconstructed as "[Witness: 'Ur]-Tešabu, son of $\mathrm{Nu}$ ' mï-Rašap".

${ }^{62}$ Malbran-Labat and Roche, "Urtēnu Ur-Tešub."

${ }^{63} \mathrm{RS} 23.495$, found in the Ville sud. 


\subsection{Summary: The Prominence of Nu ' mī-Rašap's Family}

$\mathrm{Nu}$ ' mi-Rašap and two of his sons carried the title SUKKAL, which in $13^{\text {th }}$ century Ugarit, as already mentioned, was probably the logographic equivalent in Mesopotamian cuneiform of the local social reality, the official whose name is written $\underline{t}^{\prime} y$ in alphabetic script..$^{64}$ In this capacity they were not only linked with mastery of the scribal craft, but also with the inner circle of the royal government, and (very probably) with the local sacrificial cult and with exorcism. Furthermore, if we are correct in our prosopographic study of Šamī-Ba' lu son of $N u$ ' mi-Rašap, the family also had clear links with divination and with the priesthood of the storm god. ${ }^{65}$

The members of this family thus show up in virtually all aspects of Ugaritian elite life: in the administrative management of the kingdom's resources, as authorities in legal contracts (even those of international scope), as well as dominant players in the local intellectual (literary) and religious spheres of life. Traces of their activity are found in virtually all of the main archives recovered at Ras Shamra, ${ }^{66}$ with the highest concentration of their scribal activities showing up in the southern part of the city.

Equally intriguing is the fact that this period during which $\mathrm{Nu}$ ' mi-Rašap and his family were active as scribes seems to correspond more or less precisely with the period during which the use of the cuneiform alphabet was being developed, assimilated and institutionalized into the scribal bureaucracy of the palace administration.

\section{On Some Alphabetic Scribes and Their Colophons}

The scribal family of $\mathrm{Nu}$ ' mi-Rašap in the $13^{\text {th }}$ century $\mathrm{BC}$, steeped as they were in Babylonian scribal culture, may be instructively compared, and especially contrasted, with another important contemporary scribal movement at Ugarit - indeed, apparently more than a "movement", in many ways a "revolution" - involving the implementation of the cuneiform alphabet on the institutional level of the scribal bureaucracy in the palace administration for writing the local vernacular language. ${ }^{67}$

Relatively few alphabetic scribes are known by name. ${ }^{68}$ Of these, two notable examples, 'Ilimilku and Tab' ilu, are known from colophons preserved on Ugaritic "traditional texts". Taken together, their work provides a useful foil for better understanding not only the birth, development, and gradual "coming-of-age" of the alphabetic tradition over the course of the second half of the $13^{\text {th }}$ century, but also the reactions of contemporary scribes trained in other writing systems, most especially the prestigious and influential Mesopotamian cuneiform tradition.

${ }^{64}$ Van Soldt, "The Title T' Y"; Malbran-Labat and Roche, "Urtēnu Ur-Tešub."

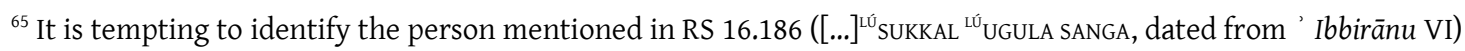
with study of $\breve{S} a m \bar{u}-B a^{\prime} l u$ son of $N u^{\prime}$ 'mi-Rašap, who is also SUKKAL and priest.

${ }^{66}$ These include the Palais royal, the Maison de Rap' ānu, the Maison de Rašap-' abu, the Maison aux textes littéraires, the Maison aux textes magiques, and last but not least, the Maison d'Urtênu.

${ }^{67}$ On the date of the cuneiform alphabet, see below, note 86 .

${ }^{68}$ In addition to 'Ilimilku, van Soldt (Studies in the Akkadian of Ugarit, 19-32) also lists bșmn (RS 15.116, KTU 4.183) and brqn (RS 19.066, KTU 3.8). Only the first letter of the scribe's name (b[...]) is preserved in RS 15.111 (KTU 3.2; see B. Kienast, "Rechtsurkunden in ugaritischer Sprache," Ugarit-Forschungen 11 [1979] 447). On the alphabetic scribe Tab' ilu, see below. 


\section{1' 'Ilimilku}

The Ugaritian alphabetic scribe best known to modern scholarship, owing not only to the early publication of tablets containing his colophon, ${ }^{69}$ but also and especially to the extraordinary nature and significance of his work ${ }^{70}$ is 'Ilimilku, who was responsible for copying most of the better known mythological texts in the local language and script. ${ }^{71}$ His work is above all characterized by large, rather carefully executed compositions written in a small script, ${ }^{72}$ and laid out in multi-column, "portrait"-format tablets with a colophon at the end. In our opinion, 'Ilimilku's choice of format, ${ }^{73}$ combined with the structure and content of his colophons, leaves little room for doubt regarding his intentions and aspirations: he was consciously imitating Mesopotamian scribal tradition, modeling the structure and format of his tablets on Mesopotamian-style "textes de bibliothèque".

The dating of 'Ilimilku is complicated, however, and has been a matter of much recent discussion. Until recently, scholarly consensus placed 'Ilimilku in the $14^{\text {th }}$ century, during the reign

${ }^{69}$ C. Virolleaud, "Fragment nouveau du poème de Môt et d'Aleyn-Baal," Syria 15 (1934) 227, 241.

${ }^{70}$ See, for example, O. Eissfeldt, Sanchunjaton von Berut und Ilumilku von Ugarit (Halle: Max Niemeyer Verlag, 1952); N. Wyatt, "Ilimilku's ideological Programme: Ugaritic royal propaganda, and a biblical postscript," Ugarit-Forschungen 29 (1997) 775-796; idem, Religious Texts from Ugarit: The Words of Ilimilku and his Colleagues (Sheffield: Sheffield Academic Press, 1998) 21-22.

${ }^{71}$ Since tablets 4 and 6 of the Ba' lu Cycle $(=C T A 4,6)$ bear versions of 'Ilimilku's colophon (that of Ba' lu 4 must be partially restored), and since only one scribal hand seems to be present throughout, it is reasonable to attribute all of the tablets of the cycle to him (thus, CTA 1-6, to which CTA 8 must now be added: cf. D. Pardee, "A New Join of Fragments of the Baal Cycle," in Exploring the Longue Durée: Essays in Honors of Lawrence E. Stager, ed. J. D. Schloen [Winona Lake: Eisenbrauns, 2009], 377-390; for full bibliography on the Ba' lu Cycle see now M. Smith and W. Pitard, The Ugaritic Baal Cycle, Vol. 2 : Introduction with Text, Translation and Commentary of KTU/CAT 1.3-1.4 [Leiden: Brill, 2009]). The same logic applies to the Kirta Cycle (CTA 14-16; tablet 3 [CTA 16] bears a short version of 'Ilimilku's colophon), to the 'Aghatu Cycle (CTA 17-19; 'Ilimilku's colophon may be plausibly restored on tablet 1 [CTA 17] on the basis of parallels), and to the recently discovered mythological fragment from the Maison d'Urtênu (RS 92.2016; RSO XIV 53; 'Ilimilku's colophon restored on the basis of parallels). Furthermore, although no colophon is preserved, the scribal hand of the Rāpi' üma texts (CTA 20-22) may nevertheless also be plausibly identified as 'Ilimilku's on paleographical grounds (Herdner, CTA, 92; D. Pardee, "Nouvelle étude épigraphique et littéraire des textes fragmentaires en langue ougaritique dits "Les Rephaïm » (CTA 20-22)," Orientalia 80 [2011] 12-14). Finally, CTA 10-12 (CTA 10-11 may be plausibly, though not certainly, joined: collation, Aleppo, 2006-2007) should also be attributed to 'Ilimilku, and in some sense grouped with the Ba' lu Cycle (same hand as CTA 1-6+8, same large multi-column tablet format, same literary genre, same "main character"; as noted by N. Wyatt, "The Religious Role of the King in Ugarit," Ugarit-Forschungen 37 (2005) 701, note 19, "the text requires a contextual anchor, which is best provided, on present knowledge, by the body of the Baal cycle"), but they cannot at present be placed sequentially within the series (among other reasons, they are uninscribed on the verso, which suggests, perhaps, that they are practice copies). Thus, of the first 24 tablets of CTA, only three (CTA 7, 9, and 13) are manifestly not the work of 'Ilimilku.

${ }^{72}$ One often encounters descriptions of 'Ilimilku's hand as being neat or careful (Herdner, CTA, 37, "écriture fine et soignée"), but often it is not so much neat as it is small (ibid., p. 5, "écriture très menue et très serrée"). Certainly, his is a practiced hand (ibid., pp. 53 and 92, "exercée"), but 'Ilimilku apparently tended to write quickly, and as a consequence, multi-element signs often show a considerable amount of variation in the placement of their constituent elements (for the example of CTA 1, see Pardee, "La première tablette du cycle de Ba' lu (RS 3.361 [CTA 1]) : mise au point épigraphique," in Le royaume d'Ougarit de la Crète à l'Euphrate: Nouveaux axes de recherche Actes du Congrès Internationale de Sherbrooke 2005, ed. J.M. Michaud [Sherbrooke, Québec: Éditions G.G.C. Itée, 2007], 105-130). Thus, on autopsy, 'Ilimilku's hand may usually be easily distinguished from the elegant, harmonious, and, above all, regular hands of many administrative and epistolary tablets produced by the "mainstream" scribal bureaucracy of the royal palace in the late $13^{\text {th }} /$ early $12^{\text {th }}$ century.

${ }^{73}$ All of 'Ilimilku's work is preserved on tablets which would be described as "Type I" multi-column tablets of the Mesopotamian tradition in the tablet typology developed by M. Civil and others. See Civil, The Series lú = ša and Related Texts, MSL 12 (Rome: Pontifical Biblical Institute, 1969), 27-28; idem, “Ancient Mesopotamian Lexicography," in Civilizations of the Ancient Near East, ed. J. Sasson, J. Baines, G. Beckman, and K. Rubinson (New York: Charles Scribner's Sons, 1995), 2308; see also S. Tinney, "On the Curricular Setting of Sumerian Literature," Iraq 59 (1999) 160 (with further bibliography), in whose system Ilimilku's production would be found on " $\mathrm{M}_{2}$ ", " $\mathrm{M}_{3}$ ", and " $\mathrm{M}_{4}$ " type tablets (multi-column tablets with 2, 3, or 4 columns per side). 
of Niqmaddu III. ${ }^{74}$ We agree with Dalix and Pardee ${ }^{75}$ that the 'Ilimilku colophons most plausibly refer instead to the king Niqmaddu IV who reigned at the end of the $13^{\text {th }}$ century and at the very beginning of the $12^{\text {th }}$ century. ${ }^{76}$

\subsection{Tab' ilu}

Until recently 'Ilimilku was the only alphabetic scribe whose work was known from multiple manuscripts. Dennis Pardee, however, has recently identified a series of paleographic and other characteristics that may be (cautiously) used as the diagnostic markers in identifying the written work of another scribe, named Tab' ilu. $^{77}$

Accepting the validity these diagnostic markers, ${ }^{78}$ it is possible to place a goodly number of alphabetic cuneiform tablets and fragments within a putative "Tab' ilu corpus". ${ }^{79}$ Taken as a whole, the corpus consists mostly of poetic texts of a mythological or otherwise religious content, thus making comparison with 'Ilimilku's preserved work (which is also poetic and mythological) all the

${ }^{74}$ See the summary in Smith and Pitard, The Ugaritic Baal Cycle 2, 7-8.

${ }^{75}$ Early statements include A.-S. Dalix, "Exemples de bilinguisme à Ougarit : Iloumilkou : la double identité d'un scribe," in Mosaïque de langues, mosaïque culturelle : Le bilinguisme dans le Proche-orient ancien, ed. F. Briquel-Chatonnet (Paris: Maisonneuve, 1996), 81-90, and D. Pardee, "The Ba' lu Myth," in The Context of Scripture, vol 1: Canonical Compositions from the Biblical World, ed. W. W. Hallo and K. L. Younger (Leiden: Brill, 1997), 241, note 3. For a thorough presentation of the argument, see now Pardee, "The Ugaritic Alphabetic Cuneiform Writing System in the Context of Other Alphabetic Systems," in Studies in Semitic and Afroasiatic Linguistics Presented to Gene B. Gragg, ed. C. L. Miller (Chicago: The Oriental Institute of the University of Chicago, 2007), 186-189. We believe that the scribe whose name is written DINGIR.LUGAL in two legal texts (RS 17.061 and RS 17.067) must be differentiated from the alphabetic scribe 'Ilimilku of the Ugaritic mythological texts. The former was probably active at the end of the $14^{\text {th }} /$ beginning of the $13^{\text {th }}$ century, and the latter a century later (such a distinction seems plausible given the high proportion of homonymy at Ugarit and the frequency of the name 'Ilimilku in particular). Van Soldt (Studies in the Akkadian of Ugarit, 27-29) had proposed the possibility of identifying the scribe of the two Akkadian juridical texts with the alphabetic scribe 'Ilimilku.

${ }^{76}$ Not all students of Ugaritic, however, have agreed with such a down-dating. M. Dietrich, "Salmanassar I. von Assyrien, Ibirānu (VI.) von Ugarit und Tudh alija IV. von Hatti," Ugarit-Forschungen 35 (2003) 134-136, for example, suggests a scenario for maintaining a $14^{\text {th }}$ century date (the tablet RS 92.2016 from the Maison d'Urtênu would be an heirloom from an earlier period); he has been tentatively followed by Wyatt, "The Religious Role of the King in Ugarit," 697, note 7.

77 D. Pardee, "Deux tablettes ougaritiques de la main d'un même scribe, trouvées sur deux sites distincts : RS 19.039 et RIH 98/02," Semitica et Classica 1 (2008) 9-38; idem, "Un chant nuptial ougaritique (RS 5.194 [CTA 24]): Nouvelle étude épigraphique suivie de remarques philologiques et littéraires," Semitica et Classica 3 (2010) 13-46. On Tab' ilu's colophons, see already the suggestion of $\mathrm{O}$. Eissfeldt, "Nachträge zu 'Adrammelek und Demarus' und zu 'Bist du Elia, so bin ich Isebel'(IKön. XIX 2)," Bibliotheca Orientalis 26 (1969) 183, note 4. The vocalization of the name is uncertain; we have followed Pardee's " $\underline{T} a b$ ' ilu" for the sake of convenience. Other possibilities include "Tub' ilu" (Hawley, Pardee and Roche-Hawley, "À propos des textes akkadiens alphabétiques conservés au Musée d'Alep," forthcoming in Études ougaritiques III, ed. M. Al-Maqdissi and V. Matoïan, Ras Shamra-Ougarit series [Leuven: Peeters, forthcoming]), or even "T̄ābi' ilu" or "T̄übi' ilu” (postulating the presence of a medial -i- binding vowel between the two onomastic elements; S. Layton, Archaic Features of Canaanite Personal Names in the Hebrew Bible [Atlanta: Scholars Press, 1990], 107-154).

${ }^{78}$ A schematic presentation of the data in tabular form will be published in Hawley, Pardee and Roche-Hawley, "À propos des textes akkadiens alphabétiques."

79 Thus far, the putative "Tab' ilu corpus" includes (listed here in the order of the publication in which an argument as being the work of Tab' ilu is advanced): RS 19.039 and RIH 98/02 [Pardee, "Deux tablettes ougaritiques de la main d'un même scribe"]; RS 5.194 (CTA 24) and several small fragments (RS 5.219-223) [Pardee, "Un chant nuptial ougaritique"]; RS 5.229 (CTA 9) and RS 5.259 (CTA 25) [Pardee, "RS 5.229: restitution d'une nouvelle signature du scribe Tab' ilu," in Scribes et érudits dans l'orbite de Babylone, ed. C. Roche-Hawley and R. Hawley, Orient \& Méditerranée 9 (Paris: de Boccard, 2012), 31-49]; the entire corpus of alphabetic Akkadian texts (RS 5.156', RS 5.199, RS 5.213, RS 5.303bis, and possibly RS 5.216) [Hawley, Pardee and Roche-Hawley, "À propos des textes akkadiens alphabétiques."]; and part of the corpus of alphabetic Hurrian texts (for example, RS 1.004, RS 5.182 and RS 5.200; perhaps also RS 24.285) [provisionally, see the description of the hands in Herdner, CTA, 255, 266-267]. We have followed Pardee in provisionally grouping these texts as the work of a single scribe named Tab' ilu, but it is also possible that this corpus represents not merely the work of one individual, but the work of several individuals who were part of the same "school". 
more pertinent. The Tab' ilu corpus differs considerably from the 'Ilimilku corpus, however, in terms of the remarkable amount of internal diversity to be found within it. This diversity may be observed on various levels: in terms of the find spots of the tablets ${ }^{80}$ diversity of tablet format and layout, ${ }^{81}$ paleographic diversity, ${ }^{82}$ and diversity of language. ${ }^{83}$ In our opinion, this level of internal diversity is best explained by the hypothesis that, as a whole, Tab' ilu's work reflects a period of innovation and experiment with the cuneiform alphabet, and not a period of regular and standardized scribal tradition.

Tab' ilu's work can be most plausibly dated to the reign of 'Ammittamru III. There are two primary arguments in favor of such a date. First, one of his manuscripts was actually found not in the Ras Shamra excavations, but in the excavations at neighboring site of Ras Ibn Hani, for which the excavators have assembled a host of arguments in favor of such a date for the archives recovered there. ${ }^{84}$ Secondly, $\underline{T} a b^{\prime}$ ilu's texts contain an archaic form of the $\{g\}$ sign (one that evokes the earlier two-stroke form) which is elsewhere explicitly attested in the few preserved Ugaritic documents which may be reliably dated to the reign of "Ammittamru III. ${ }^{85}$ It should be mentioned here, of course, that the earliest reliable evidence for the institutionalization of the alphabet among the palace scribes of Ugarit derives from the reign of 'Ammittamru III. ${ }^{86}$

${ }^{80}$ With one exception (RS 92.2016), all of 'Ilimilku's tablets were found on the Acropole, in or near the Maison du Grand-Prêtre; see van Soldt, Studies in the Akkadian of Ugarit, 212-220. Many of Tab' ilu's tablets were also found on the acropolis (numerous tablets found during the $5^{\text {th }}$ season; see above, note 79), but others were found in the Palais royal (RS 19.139); we further suspect that a few are probably also to be found in the Maison du prêtre aux modèles de foies et de poumon inscrits (to cite just one example, RS 24.285 shows several of the putative diagnostic markers of Tab' ilu's work). Most importantly, one of Tab' ilu's tablets (RIH 98/02) was found outside of the capital proper, at the nearby site of Ras Ibn Hani.

${ }^{81}$ Pardee, "Deux tablettes ougaritiques de la main d'un même scribe," 9-11; idem, "Un chant nuptial ougaritique," 13. 'Ilimilku's work is characterized by much more consistency in terms of tablet format and layout.

${ }^{82}$ Pardee, "Deux tablettes ougaritiques de la main d'un même scribe," 11-12; idem, "Un chant nuptial ougaritique," 15-17. Apart from the haste-related variants (Pardee, "La première tablette du cycle de Ba' lu"; see above, note 72), the paleographic characteristics of 'Ilimilku's hand generally much more consistent.

${ }^{83}$ In addition to Ugaritic, Tab' ilu used the cuneiform alphabet to copy texts in Akkadian and Hurrian; see above, note 79 .

${ }^{84}$ See J. Lagarce and E. du Puytison-Lagarce, "Remarques sur le matériel égyptien et égyptisant de Ras Shamra ('Maison aux Albâtres') et de Ras Ibn Hani à la lumière de données récentes sur la chronologie de la fin d'Ugarit," in The Bronze Age in the Lebanon. Studies on the Archaeology and Chronology of Lebanon, Syria and Egypt, ed. M. Bietak and E. Czerny, Contributions to the Chronology of the Mediterranean 17 (Wien: Österreichische Akademie der Wissenschaften, 2008), 153-164.

${ }^{85}$ These include the two royal land grants RS 15.111 (R. Hawley and D. Pardee, "Les dons royaux en langue ougaritique : Nouvelle étude épigraphique de RS 15.111," in Études ougaritiques II, ed. M. Al-Maqdissi and V. Matoïan, Ras Shamra-Ougarit 19 [Leuven: Peeters, 2012], 251-273) and RS 16.382 (on the form of the $\{g\}$ sign, see Hawley and Pardee, "Le texte juridique RS 16.382 : nouvelle étude épigraphique," Semitica 52-53 [2007] 16), and especially the impressions of the royal nominal seal of "Ammittamru III which carries an alphabetic inscription (P. Bordreuil and D. Pardee, "Le sceau nominal de 'Ammìidtamrou, roi d'Ougarit," Syria 61 [1984] 11-14). See the summary in Pardee, "The Ugaritic Alphabetic Cuneiform Writing System," 188-189; Pardee, "\{G\} as a Palaeographic Indicator in Ugaritic Texts," in Palaeography and Scribal Practices in Syro-Palestine and Anatolia in the Late Bronze Age, ed. E. Devecchi, PIHANS 119 (Leiden: Nederlands Instituut voor het Nabije Oosten, 2012), 111-126.

${ }^{86}$ See the summary in Pardee, "The Ugaritic Alphabetic Cuneiform Writing System," 186-189. On the possibility that RS 15.117 dates to the reign of Niqmêpa' VI, the father of 'Ammițtamru III (Márquez Rowe, Royal Deeds of Ugarit, 53-54), see now Pardee, "RS 15.117 et l'origine de l'alphabet cunéiforme d'Ougarit : rapport de collation," Orientalia 79 (2010) 55-73. 


\subsection{From Early Experiments to Scribal Tradition}

Tab' ilu can thus be plausibly dated to the reign of 'Ammittamru III in the middle of the $13^{\text {th }}$ century, and 'Ilimilku plausibly dated to the reign of that king's grandson, Niqmaddu IV, at the end of the $13^{\text {th }} /$ beginning of the $12^{\text {th }}$ century.

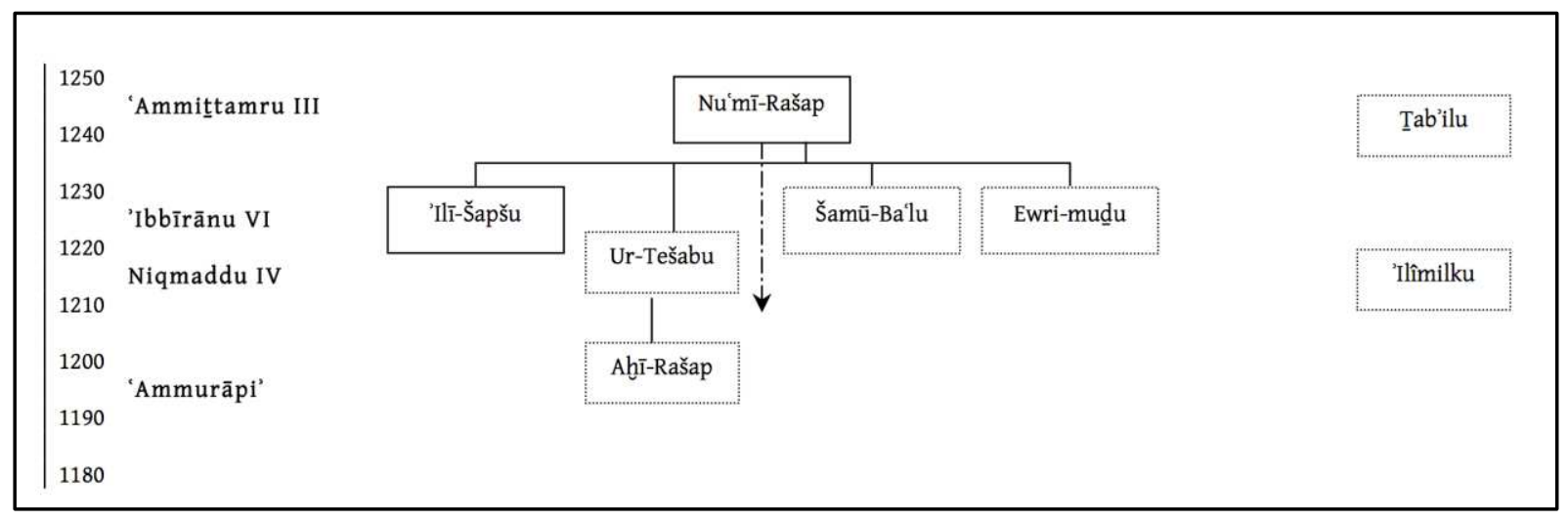

fig. 3. Schematic diachronic presentation of $\mathrm{Nu}$ ' mī-Rašap's family with respect to two alphabetic scribes

Such a relative chronology, in our opinion, provides a simple and reasonable explanation for the evolution that can be observed in terms of alphabetic scribal practices in the intervening generation or two. By the time of 'Ilimilku, the cuneiform alphabet was less of an oddity, less of an experiment. The scribal habits to be seen in 'Ilimilku's work suggest a certain maturity - or, at least, a "coming-of-age" - for the alphabetic tradition: the regularity of the sign forms, regularity of the mise-en-page and of tablet shape, the presence of "standard" sign forms (that is, forms which are in general usage by the scribes of the administrative and epistolary tablets). Such is less the case in Tab' ilu's work: his tablets show a bewildering variation in sign forms, and considerable latitude in tablet shape and mise-en-page. To these observations we may add the presence of archaic sign forms (and more generally sign forms not in general usage by the scribes of the administrative and epistolary tablets). One must certainly hesitate to convey esthetic judgments, and yet it is difficult to escape the impression of a certain clumsiness in Tab' ilu's work, as if he was working without the benefit of well-known, well-established models.

\section{Conclusions: Family Traditions versus Individual Innovators?}

By emphasizing the fact that they belonged to prestigious scribal families, the local scribes of Ugarit working in Mesopotamian script, as exemplified by Nu ' mï-Rašap's family, were insisting on the fact that they themselves belonged to, and were perpetuating, the prestigious intellectual tradition of the Mesopotamian scribal arts.

Even though the alphabetic scribes, and especially ' Ilimilku, appear to have modeled certain aspects of their compositions on Mesopotamian models, judging from the available evidence ${ }^{87}$ they nevertheless did not adopt the "son of X" element in their colophons. Rather than insisting on belonging to and perpetuating a tradition, the alphabetic scribes would thus seem instead to be affirming their independence, affirming the fact that they and their work represent not continuity but instead a profound rupture with previous scholarly tradition (a rupture which, incidentally, would turn out to be more or less irreversible for the Levant). This rupture can be observed not only in the

\footnotetext{
${ }^{87}$ Caution is obviously required here since the body of data is so limited: in the literary corpus we have only four colophons attributable to 'Ilimilku, and two (very short) colophons for Tab' ilu. Note that the alphabetic colophons known from non-literary texts, such as those of brqn and bșmn, however, also omit patronymics.
} 
choice to omit the mention of fathers, but also in the choice to write the local language (instead of the traditional Mesopotamian languages of learning), and to use a locally developed alphabetic script (instead of the traditional Mesopotamian cuneiform script).

In at least two of his colophons ${ }^{88}$ for example, 'Ilimilku fills the expected "son of X" slot with a gentilic adjective, as if to convey that he is not the son of anyone particular, rather he is from the village of Šubbānu. The repeated presence of this element in his colophons suggests that the scribe was apparently proud of his provincial origins. Is it legitimate to see here an intentional desire on the part of 'Ilimilku to detach himself from the scribal traditions of the capital, as represented by $\mathrm{Nu}$ ' mï-Rašap's family?

A second example comes from the most recently discovered 'Ilimilku colophon, that of RS 92.2016, ${ }^{89}$ in which the scribe seems to be parodying another traditional Mesopotamian colophon motif: that of the copied work being checked, verified, and complete..$^{90}$ The most obvious reading for the phrase $w$ ' ind $y l m d n n$ in the third line of the colophon is "nobody taught it (to me)". ${ }^{91}$ In other words, 'Ilimilku seems to be conveying that the text does not contain traditional material that could be checked, but rather original new material of his own creation.

Still further illustrations of a potential tension between the old prestigious scribal families steeped in age-old Mesopotamian lore on the one hand, and the alphabetic scribes, the "young turks" as it were, on the other, may be found in the Mesopotamian cuneiform corpus. Perhaps, for example, we might interpret the proliferation of "learned" spellings, esoteric writings, and graphic puns, ${ }^{92}$ all of which are especially well attested with $\mathrm{Nu}^{\prime}$ mi-Rašap, as a kind of reaction to the alphabetic enterprise on the part of local scribal establishment. Most of these "learned" writings are best characterized not as archaisms, but as examples of attempted archaizing: intentionally "oldlooking" spellings, even intentionally obscure spellings. Is it coincidence that these kinds of writings are particularly visible in the mid- $13^{\text {th }}$ century, just when the palace has more or less officially adopted the alphabetic cuneiform script as the vehicle of domestic administration, that is, just when the Mesopotamian tradition's age-old monopoly on scribal privilege has been threatened?

However we answer that question, a few decades later, by the end of the $13^{\text {th }} /$ beginning of the $12^{\text {th }}$ century, the tension seems much less apparent, and perhaps has even been resolved altogether. ${ }^{93}$ Bi-graphic compositions are more common, ${ }^{94}$ as if nothing could be easier that the

${ }^{88}$ RS 2.[009] ${ }^{+}$viii 53 (CTA 6); RS 92.2016 (RSO XIV 53). The word šbny should also be reconstructed in the colophon on the left edge of RS 2.[004] (CTA 17).

${ }^{89}$ A. Caquot and A.-S. Dalix, "Un texte mythico-magique (no 53)," in Études ougaritiques I, ed. M. Yon and D. Arnaud, Ras Shamra-Ougarit 14 (Paris: Éditions Recherche sur les Civilisations, 2001), 397.

90 Though rare, such an element is nevertheless found in the colophons of locally copied Mesopotamian traditional texts: for example, RS 20.032 (MU.BI AL.TIL, "its lines have been completed”) and RS 20.201A+ (MU.BE AL.[TIL IG]I.KÁR , "its lines have been completed and collated"); van Soldt, "The Title T' Y," 315.

${ }^{91}$ Caquot and Dalix, "Un texte mythico-magique," 397.

${ }^{92}$ Roche 2008a: 210-214; see above, section 3.

${ }^{93}$ For the example of Ur-Tešabu's seal on a label with a Ugaritic inscription, see Malbran-Labat and Roche, "Urtēnu Ur-Tešub," 85-86; see also section 3, above.

${ }^{94}$ C. Roche, "Classification de l'utilisation du cunéiforme mésopotamien dans les textes ougaritiques," in Proceedings of the 51st Rencontre Assyriologique Internationale Held at the Oriental Institute of the University of Chicago July 18-22, 2005, ed. R. Biggs, J. Myers, and M. Roth, Studies in Ancient Oriental Civilization 62 (Chicago: The Oriental Institute of the University of Chicago, 2008), 155-170. This phenomenon is especially prominent in the Maison d'Urtênu. Perhaps it should be linked with the presence of Ur-Tešabu as a scribe there (Malbran-Labat and Roche, "Urtēnu Ur-Tešub")? Well-trained as he was in Mesopotamian cuneiform tradition, Ur-Tešabu was possibly attracted by the "new" alphabetic cuneiform system (as were other local scribes; see Hawley, "Apprendre à écrire à Ougarit," 229-232); having been raised in an intellectual milieu, he perhaps "played" with the cuneiform alphabet, just as he had learned to "play" with the readings of logograms (Roche, "Jeux de mots, jeux de signes"). 
combination of the two scripts. And bi-graphic scribal exercises show that students learned and used both systems simultaneously, even in the proud family of $\mathrm{Nu}$ ' mi-Rašap. ${ }^{95}$

${ }^{95}$ RS 94.2273, for example, contains model letter (epistolary formulas) in alphabetic Ugaritic on one side and an extract from the Silbenalphabet A in Mesopotamian cuneiform on the other (P. Bordreuil, D. Pardee, and R. Hawley, Une bibliothèque au sud de la ville, vol. III: Textes 1994-2002 en cunéiforme alphabétique de la Maison d'Ourtenou, Ras Shamra-Ougarit 18 [Lyon: La Maison de l'Orient et de la Méditerranée, 2012], 205-206 (n 79); Hawley, "On the Alphabetic Scribal Curriculum at Ugarit," in Proceedings of the 51st Rencontre Assyriologique Internationale Held at the Oriental Institute of the University of Chicago July 18-22, 2005, ed. R. Biggs, J. Myers, and M. Roth, Studies in Ancient Oriental Civilization 62 [Chicago: The Oriental Institute of the University of Chicago, 2008], 63, note 46). If the kinship terminology used in the model letter is to be taken literally rather than metaphorically (which we consider probable in this case), the scribe who did the exercise - a woman named 'Abinaya - was the sister of Ur-Tešabu, and therefore the (cadette?) daughter of Nu ' mī-Rašap. 